\title{
VERTALING VAN SARGA XIX VAN HET OUDJAVAANSCHE RĀMĀYANA.
}

\author{
DOOR
}

\author{
Dr. H. H. JUYNBOLL. ${ }^{1}$ )
}

\section{Sarga XIX.}

Vervolgens nadat zij vruchten gegeten hadden, was het geheele apenleger volkomen verzadigd. $\mathrm{Zij}$ werden hoe langer hoe onstuimiger en wilder; ongeduldig beraadslaagden zij, wenschende de vijanden te verdelgen (1).

Ook het leger der rākșasa's was ongeduldig; nadat zij gegeten hadden, beraadslaagden zij luidruchtig en drinkende. $\mathrm{Zij}$ sneden $(\text { vleesch ? })^{2}$ ) en tooiden zich met goud en edelgesteenten. Hun gelaat en borst was vol blanketsel en zij waren allen versierd met bloemen (2).

Daarna stonden zij op en vatten hunne (wapens) op: knotsen, dolken, krtala's ${ }^{3}$ ), lori's, muçala's (soorten knotsen), bijlen, werpspiesen, speren met ploegscharen, pijlkokers, bogen; drietanden, speren, verschillende wapens en bijlen (3).

$\mathrm{Zij}$ gingen uit de voortreffelijke burcht en het gebouw; de vaandels en vlaggen werden alle omhoog gestoken. ${ }^{4}$ ) De paarden werden gepantserd en de olifanten in krijgsgewaad gekleed. De wagens werden gevuld met allerlei wapens (4). ${ }^{5}$ )

Terwijl de heldhaftige rākșasa's schreeuwden en luidruchtig juichten, ongeduldig wachtende, was Rāwaṇa bezorgd, verbijsterd van geest, hoorende dat Rāma op den Suwela was (5).

De nevel en duisternis van zijn hart namen hevig toe, alsmede zijn

1) Sarga XVIII is vertaald in deze Bijdragen, deel 85, p. 291-296.

2) Het woord „vleesch” heb ik ingevoegd, omdat maněrwěri anders geen object zou hebben.

3) Welk wapen hieronder verstaan wordt is mij onbekend.

4) Pinasang beteekent eigenlijk: ,,aangewend, toegepast, gebruikt worden”.

5) Praharanakalikā is tevens de naam van een versmaat. Vgl. Writtasañcaya, 75. Ook de beide laatste woorden van het vorige vers: sapraharaṇa kuliça zinspelen hierop. 
nijd, hartstocht en afgunst. „Deze Sitā zal ik dooden, (zoodat) zij noch van $u$, noch van mij is", dacht hij bekommerd (6).

Hij peinsde over (hare) onreinheid en schande op aarde, over de slechtheid der vrouwen, die zeer vreeselijk is. Toen verhief zich zijn eigenwaan en zijne dapperheid. Zijn geest werd vertoornd en dit veroorzaakte, dat hij zou sneuvelen op het slagveld (7).

Hij riep zijne raadslieden op, patih Prahasta en Mahāpārçwa en hem, die Ghațodara heette, alsmede Wirūpākṣa, Wilohitākṣa en Yupākșa, den zesden der voornaamste mantri's (8).

Degenen, die zeer krachtig waren, de legeraanvoerders: Mitraghna en Praghasa, Prajanggha, Jambumālī, hij die Açaniprabhā heette, Dhūmrākṣa, Akampana, Bajramușți (9).

Dewāntaka, de zoon van Daçāsya, Narāntaka en Triçirạ̣ en Trikāya, de zonen van zijn jongeren broeder Kumbhakarṇa, vermaard in de wereld, Nikumbha en Kumbha (10).

Dit waren de mantri's en helden van het leger. Hunne troepen telden honderdduizendtallen. Zij beraadslaagden, de groote helden, het puikje der strijders. Scherp en puntig waren hunne wapens als Indra's bliksemflits ${ }^{1}$ ) (11).

Toen alle räkșasa's bevolen werden, om ten strijde te trekken, werden de voortreffelijke horens geblazen ten getale van honderden en honderdduizenden. Hun geluid was zeer geducht en zij schetterden luid als de bliksem, (zoodat) de zeven onderwerelden trilden. De aarde, het luchtruim en de hemel overstroomde, alsof datgene, wat het wereldruim heet, zou splijten en inzakken (12).

En honderdduizendtallen, honderd millioenen trommen weerklonken met een hevig diep geluid; als zij geslagen werden, was het als de wolken bij de vernietiging der wereld, die een donderend geluid maken, en de aarde schudde en beefde. De harten der menschen werden daardoor doorboord en sidderden aanhoudend; geducht waren de bekkens. De trommen (mardala) weerklonken aanhoudend en de pauken (pațalıa) en mahāsāra's ${ }^{2}$ ) wedijverden met de koperinstrumenten (13).

Vele paarden hinnikten, alle bedreven in den strijd, in het verpletteren en vertrappen van ieder, die hen tegemoet trad. De olifanten brulden daverend, alsof het rijk Langkā verdelgd werd en wankelde.

1) Indrabajra is de naam van een versmaat (Wṛttasañcaya, 44).

$\left.{ }^{2}\right)$ Welk muziekinstrument hieronder verstaan wordt, is mij niet bekend. Volgens Mr. J. Kunst (Hindoe-Javaansche muziekinstrumenten), p. 81, is mahäsāra de naam van een gong, wat hier ook goed zou passen. 
De reeën in het dichte woud schrikten; sommige waren ontsteld en bezinningsloos van angst; ten gevolge van het zeer vreeselijke, geduchte geluid, (was het) alsof de bergen zouden instorten, vallen en vernield worden (14).

De helden waren uitermate verheugd over het weerklinken van de ontelbare horens en trommen. Hoe langer hoe meer haastten zij zich, om ten strijde te trekken. Sommigen stonden op en allen hieven een leeuwengebrul aan. Zij namen hunne lansen en messen ter hand en grepen hunne werpspiesen en candrahāsa's. ${ }^{1}$ ) Onmiddellijk daarop schreden zij voorwaarts en verheugd dansten de helden, bedreven in de vijf soorten van wapens (15).

Zij die ervaren waren in de olifantenkennis reden op bronstige en woeste olifanten. Zorgvuldig zaten zij te paard, met een dolk in de hand, zij die bedreven waren in de paardenkennis. Andere rākșasa's waren vermaard door hunne kennis van de leerboeken der boogschietkunst. Allen maakten zich gereed en bestegen hunne wagens. Sommige wachtten op hunne zeer krachtige wagenmenners (16).

Vreeselijk van uiterlijk waren de rākșasa's, die messen droegen, alle met verschillende gevesten. ${ }^{2}$ ) De steelring ${ }^{3}$ ) van hunne dolken was van rood goud, waartusschen diamanten flikkerden. Buitengewoon waren hunne gevesten in leeuwengedaante, geducht als de dood. Degenen die hen zagen sloten de oogen. Zelfs god Kāla was geschokt, bevreesd bij het zien van hen, die (zoo) gruwelijk en vervaarlijk waren (17).

De krachtigen braken op, met ijzer gepantserd. De wegen waren vol en door hen versperd. „Vooruit! Stoot de voorsten, loopt door, zonder ophouden!" zoo sprak men wegens het gedrang. Evenzoo waren hunne wapens blinkend, groote bijlen, die vijf vallemen breed waren. Wanneer zij de vijanden in den strijd doorsneden, (zooals) vroeger, deden zij dat niet voor de tweede maal (18).

$\mathrm{Bij}$ het vertrek der juichende helden weerklonken de trommels luid langs den weg en werden de horens geblazen. De gemalinnen der helden waren verheugd; zij lachten van vreugde bij het zien, dat hare echtgenooten zouden uittrekken. $\mathrm{Zij}$ steunden op hunne geliefden onder het loopen en vergezelden hen tot buiten het paleis. „Heer!

1) Candrahāsa is de naam van een snijdend wapen.

2) Volgens den samenhang moet szuāngga hier ,gevest” beteekenen en niet ,kleedingstuk".

3) Wintang-wintang beteekent etymologisch „gesternte”, maar hier moet het „steelring" beteekenen. 
Wees toch op uwe hoede en streef naar roem!' Zoo spraken zij, afscheid nemend en een sěmbah makend (19).

Niet zoo waren (andere) vrouwen, die zeer bevreesd waren en weenden; velen begonnen onwillekeurig te wateren, terwijl zij zich bukten. Allen waren bij het zien voorover gebogen, nederhurkende, treurig, deerniswaardig ten gevolge van hare liefde. De helden waren eveneens bij het zien daarvan bedroefd en deerniswaardig, hunne tranen met moeite bedwingende. Zij keerden terug, hunne geliefden geleidende en kussende en een oogenblik omhelzende, terwijl zij hare tranen afwischten (20).

Vriendelijk en liefelijk waren de vrouwen, die pas de liefde hadden leeren kennen, en weerstrevende spraken zij snel: „Heer! Wacht toch! Ach! Gij zijt niet welwillend, daar ik juist bedroefd en smachtend ben. Haast $\mathrm{u}$ niet! Ik zal met $\mathrm{u}$ sterven en mij in het vuur storten, als gij sterft." Zoo waren hare woorden. Verliefd wachtten de helden, terwijl zij afwisselend de voortreffelijke vrouwen troostten (21).

Zij waren kwijnend en afgemat; er waren er, die juist de lusten hadden, teeder en liefelijk was haar blik. Stralend, ${ }^{1}$ ) liefelijk en schoon was haar blik, die liefde inboezemde en het hart der minnaars aantrok. Dicht was haar haarwrong, zwart, glad, fijn en bekoorlijk, op hare wangen. Haren echtgenoot roepende, trachtten zij te loopen, (maar) hare knieën knikten en hare beenen waren zwak (22).

„Heer! Keer toch terug! Gij zijt toch werkelijk zeer liefdeloos en niet smachtend, doch ik zal niet achterblijven. Ik zal $\mathrm{u}$ vergezellen en met $u$ meegaan, ik zal niet scheiden van uwe voeten. Als gij wilt sterven, zal ik niet anders doen, ik zal zelfmoord plegen en amok sterven, zal ik niet anders doen, ik zal zelfmoord plegen en amok makende sterven. Ten gevolge van mijn trouw wordt gij alleen beschouwd als een beeld in mijn hart (23).

„En als ik achterbleef, wie zou dan zooals gij mijn lichaam behoeden en beschermen? Alleen tot $\mathrm{u}$ wend ik mij weenend om bescherming, als de tijd van leed komt, want gij zijt mijn geliefde vriend. Ik heb geen bloedverwanten en vader en moeder heb ik nooit gezien, wegens mijn schuld, omdat ik weggeloopen ben naar $\mathrm{u}$. Vurig verlang ik en neem geen afscheid" (24).

1) De betekenis van mapwaypway blijkt niet duidelijk uit de O. Jav. woordenboeken. Bij van der Tuuk ontbreekt het en de beteekenis in mijn O. Jav. woordenlijst (p. 393) past hier niet. Dr. Aichele (Grundsätzliches zur KawiInterpretation, Feestbundel Bat. Genootschap, I, p. 10) vertaalt hẹt mẹt „lieblich strahlend" en brengt hẹt ịn vẹrband mẹt Sund. pozve (dag). 
Zoo spraken zij, verliefd, een sěmbah makende. Het hart van den held smolt en hij wilde mingenot smaken, ten gevolge van zijne begeerte, doch zij verzette zich hiertegen, daar zij juist zwanger was. Haar hart brak en hare tranen waren onstelpbaar bij de gedachte aan hare liefde en hare deerniswaardigheid. De hevigheid van den hartstocht en de liefde brengt het hart der menschen, die nu eenmaal menschen zijn, in beroering (25).

„Vorstin, wees niet verlangend! Keer naar huis terug, zusje, wacht gij allen daar, onbewegelijk! Uw gemoed is zeer afgemat en ook hebt gij de lusten; uwe voeten zijn zacht en zwak. Ik bestrijd gevaren en bevind mij in het verhemelte van den dood, waarin het moeielijk is te leven. Het is jammer, o vorstin! draag zorg voor de schoonheid van uw lichaam en uw buik, zusje, is zwanger (26).

„En ik zal niet sterven, zusje, doch de vijand zal sneuvelen en zeker zal Raghu's telg overwonnen worden, want uw heer is machtig in de drie werelden en hier in Langkā is men hem onderdanig. Wacht toch, geliefd zusje! Ik zal niet overwonnen worden. Kus uw man, die afscheid neemt, om uit te trekken". Zoo waren de woorden van den held; daarop ging hij weg, terwijl zijn gemoed voortdurend gekweld werd (27).

De liefhebbende rākșasa was bedroefd en weende om zijn kind; zijn hart was gebroken van liefde. Snel droeg zij het op de heup, omarmde en kuste het en gaf het na een oogenblik aan zijne geliefde: „Vorstin! Draag uw kind, liefkoos het en verzorg het! Vergeet niet, er zorg voor te dragen! Waarlijk, wanneer ik sneuvel op het slagveld, laat dan mijn geliefd kind goed door u verzorgd worden" (28).

Zoo waren de woorden, die de rākșasa sprak. Het was alsof het hart der bedroefde vrouw gebroken werd. Zij sprak niet en nam haar kind niet op, omdat zij vermoeid was en hare tranen neervielen en hare liefde verdwenen was. Hare gewrichten waren pijnlijk bij het omarmen der voeten en hare ellebogen waren zwak en haar weenen was heesch. De held was zeer medelijdend, zoodat hij haar omhelsde en haar op het rustbed legde (29):

„O vorstin! Laat uw leed varen, want dit is niet de reden, dat ik u kom opzoeken. Niet verdiet is de oorzaak, dat gij u geluk ondervindt en van uw geluk in het hiernamaals. Alleen uw trouw verlost iemand zooals gij, vorstin. Wanneer eene vrouw niet trouw is, zal zij zeker scheiden en in de Aweci-hel vallen (30).

„Zoo ịs de handẹlwijze van iemand zooạls ịk, diẹ mij als diẹnaạr 
beschouw en de voeten van den vorst dien. Al zijne woorden en bevelen worden door zijne onderdanen steeds ten uitvoer gebracht. Als wij dit echter niet doen, zullen wij zeker hiernamaals in de hel gekookt worden. Dit is de reden, dat ik van u afscheid neem, om dapper ten strijde te trekken en verwoed te strijden" (31).

Nadat de helden zoo gesproken hadden en hunne vrouwen omtrent den inhoud der wetboeken ingelicht hadden, werd haar gemoed bevredigd en hielden zij op met weenen, trouw de woorden van haren echtgenoot opvolgende. $\mathrm{Na}$ met haar geminnekoost en mingenot gesmaakt te hebben, trokken de helden uit, niet langer verslapt. De voortreffelijke vrouwen versierden zich en stonden vervolgens op, met rokken, die met kransen ${ }^{1}$ ) getooid waren, terwijl zij een š̆mbah maakten (32).

Bij het uittrekken van het dappere leger der rākșasa's onder luid geraas, werden zij vervolgens gelast, aan de leidende patih's hun taak aan te wijzen. De beroemde Prahasta was de oudste in den strijd. Deze bevond zich in het Oosten van de stad bij de opstelling in slagorde (33).

Ghatodara was de buik (het centrum) in den strijd benevens patih Mahāpārçwa. Hij was het puikje, die het Zuiden bewaakte, reeds geheel gereed. De voortreffelijke held Meghanāda werd gelast, hem bij te staan. Hij bevond zich gereed in het Westen en stelde hen, die zich in het Noorden bevonden, in slagorde (34).

Wirūpākșa was voornemens, het binnenste van de stad te bewaken. Hij beval zijne makkers, naar binnen te gaan en de vergaderzaal te bewaken: „Wacht hier en houdt hier de wacht en brengt hier alle wapens! Overstelpt den vijand, als hij komt en vlucht niet, als gij met pijlen beschoten wordt!" (35).

Zoo sprak de mantri tot zijne onderdanen, waarop zij snel binnentraden. Er was niemand, die niet volledig toegerust was. Allen grepen hunne wapens en waren krachtig in het standhouden. „Zonder ophouden moet gij allen binnenkomen", zeide hij, hen oproepende. Hij riep het volk op, dat gezamenlijk een vreeselijk rumoer maakte (36).

Hun toorn vlamde op, om snel het apenleger te verdelgen. $\mathrm{Zij}$ waren gewelddadig, ruw, zich verbijtende, schaterende, vreeselijk, met opengesperden muil. Hun geest was besloten om den zegevierenden Rāma te dooden. Wij zullen overwinnen, dachten zij, omdat zij overmoedig en steeds zeer dom waren (37).

\footnotetext{
1) Sragdharā is de naam van een bekende versmaat (Wṛttasañcay'a, 92).
} 
Zij wisten niet, dat zij verslagen en zelfs met hunne geheele geslacht verdelgd zouden worden. Hun twijfel verdween bij het zien van kraaien en wilde honden. Ontelbaar en zooals nooit gezien was kwamen deze en maakten een luid geraas, alsof zij verheugd waren. Hunne vreugde was daarover, dat de booswichten, alle rākșasa's zouden sterven (38).

Toen het leger van Daçāsya geheel gereed was en allen gewapend waren, keek Rāma, dat hoorende, Lakṣmaṇa aan. Zijn jongere broeder, die verstandig was, begreep het snel, toen hij aangekeken werd. Behoedzaam stond hij op en eerbiedig, terwijl hij alle apen opriep (39).

Zij die de voornaamste en krachtigste en oudste van alle apen waren: Anggada, Susena, Nīla, Nala, Jāmbawān, Māruti en Marut's zoon, Sahasra, Hari, Mainda, Bhimamukha, Mattahastī, Gaja, Gawākșa, Winata, Indrajānu, hij die Çarabha heette en Sampāti (40).

En Çatabalī, Dhruwa, Drawiḍa, Dhūmra, Tāraprabha, Çubhodara, Karālawaktra, Kumuda, Pralambodara, Wisangkaṭa, Puțākṣi en Wṛṣabha, Kṛ̣ṇa, Singhānana, Darīwadana, Gandhamādana, Dhanurdhara en Ākrandana (41).

Dit waren de aanvoerders van het apenleger, heldhaftig in den strijd. Uitgelaten hieven zij een leeuwengebrul aan en allen waren verheugd en juichten luid. Tegelijk knotten zij den berg af, den top van den Suwelaberg en het geboomte er van trokken zij zonder overschot uit (42).

Vlakke steenen, die hard en scherp waren, werden door hen afgebroken zonder einde(?). Deze dienden hun tot wapen, dat zij droegen, geheel gereed. De edele Rāghawa was verheugd, ziende dat zij allen volledig toegerust waren. Hij bracht hulde aan god Çatarudra en nam afscheid (43).

Er waren achthonderd gelukvoorspellende loftuitingen, om zijn heil te bewerken, hem geschonken, om zich zelf te beschermen, toen hij nog een kind was. Zijne reinheid was de oorzaak van zijn zegepraal en van een lang leven. Deze sprak hij alle uit en vertrok daarna (44).

Bij zijn optreden bewoog zich plotseling de aarde en beefde. Een bloedregen langs den weg, dat was een voorteeken van zijne overwinning. De reebokken vluchtten aan zijn linkerkant, hun weg was gunstig en het gekweel der vogels was zacht en bekoorlijk en veroorzaakte vreugde (45).

Vóór hem vielen onder verbazend gebulder vuurklompen en ontelbare wilde honden huilden, hem tegemoet gaande. Deze gunstige 
teekenen zag hij wel, doch hij vertrouwde ze niet. Het is de aard van hem, die naar het schoone streeft, om zeer twijfelmoedig te zijn (46).

Wibhịsana, die ervaren was in het verklaren van voorteekenen, sprak: „Koningszoon, o voortreffelijke Rāma! Er is geen twijfel aan. Zeker zal de vijand verdelgd worden en zult gij overwinnen in den strijd. Dat deze voorteekenen zich vertoonen is de reden, dat ik overtuigd ben" (47).

Zoo waren zijne woorden. Het gemoed van den vorst was uitermate verheugd en alle voornaamste apenhelden waren allen verblijd. $Z \mathrm{ij}$ werden hoe langer hoe ongeduldiger, om alle boosdoeners te verslaan bij het hooren van de gunstige uitlegging ${ }^{1}$ ) van Wibhīṣaṇa aangaande de goede voorteekenen (48).

Bij hun komst in de nabijheid van de stad en het rijk Langkāpura hieven zij allen een leeuwengebrul aan als woeste en vertoornde leeuwen. Hunne oogen schitterden, hunne nagels waren hard en hunne slagtanden scherp, alsof zij de dienaren van den Doodsgod waren, die de zielen der rākşasa's weghaalden (49).

Zij traden naar voren, naar het Zuiden gewend. Vervolgens stelden zij zich in slagorde, de plaatsen verdeelende. In grooten getale verspreidden zij zich en breidden zich rondom uit, in het Westen en Zuiden. Andere bevonden zich ten Oosten van de hoofdstad, in dichte massa's. Onvergelijkelijk, als eene overstrooming waren de apen, luidruchtig en daverend (50).

Het zand aan den oever van de zee, wie zou dat kunnen tellen? Evenzoo was het apenleger, want het was zeer talrijk; zij waren ontelbaar, zoodat het Noorden en Zuiden door hen versperd was, die dicht opeen in rijen geschaard waren. Geheel Langkāpura was gevuld, bedekt $\ldots{ }^{2}$ ) en overstelpt (51).

Het was nog niet de helft, die daar gekomen waren; verscheidene waren nog niet gekomen. Zij kwamen onafgebroken van den Suwelaberg. Anderen hadden pas den Suwela-berg bestegen, zonder tusschenruimte. Men zag hen dicht opeen en anderen waren pas (de zee) overgestoken (52).

Evenzoo waren zij, die op den berg Mahendra waren, nog niet op weg, ten getale van honderd duizend, tien millioen, honderd duizend, millioen en honderd millioen. Vermoeid stonden zij te wachten op

1) Pamujī, dat gewoonlijk ,eerbewijzing” beteekent, moet hier opgevat worden, zooals hierboven vertaald is.

2) Voor kakanda geven de woordenboeken geen, hier bruikbare beteeken.s, 
hen allen, die overstaken. Zij gabberden, verheugd, gehurkt, op zijde gaande en anderen knikkebolden (53).

Hoe meer er kwamen, des te meer wankelden zij en trilden en maakten een verward geraas. Zij stieten (elkander) omver, onophoudelijk sschreeuwende, verward dooreen wegens het gedrang, alsof de grond zou splijten en alsof de bergen zouden barsten, alsof de hemel zou instorten door het geraas der apen (54).

Vreeselijk stonden zij klaar en beraadslaagden, hoe zij alle rākșasa's zouden overstelpen. Van wege hun toorn draaiden zij hunne handen rond en verbeten zich. Hunne haren waren lang en fijn en rossig; zij wapperden alsof het een vuurzee was, die de rākșasa's kwam verbranden (55).

Op verschillende wijzen gedroegen zij zich, ongeduldig(?), $\left.{ }^{1}\right)$ omdat zij zich haastten om te strijden. $Z$ ij riepen en stonden op, om vooruit te trekken en dansten, vooruit schrijdende. $\mathrm{Zij}$ makten verheugd een š̌mbah, anderen trokken de wenkbrauwen op, zeer verheugd. Als schoone maagden beschouwden zij de vijanden, zonder hen te vreezen (56).

$\mathrm{Zij}$ werden gelast te wachten en niet dadelijk ten strijde te trekken, want zij waren inderdaad helden, die zich verweerden, nadat zij gewond waren. De eersten om te strijden op het slagveld, degenen die de middelsten waren strekten niet tot weg van de voortreffelijkste helden (57).

De apenvorsten waren onderricht in de wetenschappen en men had hen geleerd, het Noorden en het Zuiden te onderscheiden. Er was geen in staat, on de bevelen op te volgen, want zij waren vluchtig van aard en dom, doch niet weerspannig. De macht van den voortreffelijken telg van Raghu was in staat om de geheele wereld te beheerschen (58).

Onder alle patih's was er geen, die zich verzette tegen zijne bevelen. De apenvorsten waren verheugd en blijde, ingetogen, bedaard en vastberaden. Zij toefden, er op wachtende, dat de rāassasa's zouden vooruittrekken, doch hun gemoed was ongeduldig, eene herinnering aan hun apenaard (59).

Aan Daçānana werd bericht, dat de apen hem kwamen overstelpen. Hoe langer hoe meer sidderde zijn gemoed en hij was mismoedig en bevreesd, doch hij liet niet merken, dat hij door vrees getroffen was, zooals de aard van een vorst is, verborg hij alle droefheid in zijn gemoed en liet hij die niet merken (60).

1) Tan duga-duga beteekent gewoonlijk: „onoprecht”, doch dit past hier niet. 
Hij stond op en ging snel naar buiten om te kijken. Hij keek naar de omstreken van de residentie, doch er was geen veld, geen bosch of dal te zien, want alles was bedekt en vol en gevuld met apen (61).

Het gevaar was dreigend, ${ }^{1}$ ) ziende hoe verspreid de apen waren. Zij vertoonden zich zonder grenzen, evenals de zee, wanneer deze davert, en de heuvels, die zij afgebroken hadden, waren te vergelijken met klippen. Als een door storm gebeukt ravijn was, naar zijne meening, de stad, die overstelpt werd (62).

Er was geen middel, peinsde hij, en het was onvermijdelijk, doch de hoogmoed van zijn koninklijken aard en zijn eigenwaan verhief zich. Hij gelastte zijn leger vooruit te rukken en woedend te strijden op het slagveld, want het is de gelofte van hem, die de heerschappij verworven heeft, te zullen sneuvelen in den strijd (63).

De legerhoofden, alle helden, traden toe op Indrajit. De vorsten werden gelast vooruit te trekken, om de helden in de pan te hakken in den strijd. Zij traden naar voren met het gelaat naar het Noorden gewend. $Z$ ij waren allen volledig toegerust. $Z$ ij werden allen ingedeeld en in slagorde geschaard, in rijen geplaatst, gerangschikt en in deelen gesplitst (64).

De voorste op het veld waren de wagens, de voetgangers en de paarden. Zij, die met hamers en bogen gewapend waren, werden gelast zich te bevinden in het kreupelhout. De olifanten waren de voorste in het moeras en werden gebruikt voor (het doorwaden van) breede en diepe rivieren. Alle gepantserden, zeer sterk, waren in de ravijnen van het gebergte (65).

$\mathrm{Zij}$, die uittrokken in het veld, stelden zich op en schaarden zich in slagorde. Het voetvolk in het midden waren allen aan de zijde van de paarden. Achter de voetknechten waren de wagens op een rij, om hen te beschermen. De naam ervan was Makarānana, beroemd als de voornaamste der slagorden (66).

De bereden troepen waren in rijen in het centrum geschaard. Het leger der voetknechten flankeerde hen, allen in rijen geschaard. Daarop volgden alle wagens, vijf honderd, ter bescherming. De naam ervan was Bajrapañjara, zegevierende over moeielijk te overwinnen vijanden (67).

De voetknechten liet men aansluiten( ?), $\left.{ }^{2}\right)$, zich bevindende in het centrum. De bereden troepen omgaven hen, doch gingen niet vooruit.

1) Deze vertaling van de woorden: ikang bhaya ya kob'ay'an is onzeker.

$\left.{ }^{2}\right)$ De vertaling van kaluundula is twijfelachtig. 
volstrekt niet ver verwijderd. De wagens dekten de paarden; dit heet de Sucimukha, van ouds vermaard als in staat, om den geheelen aardbodem ${ }^{1}$ ) te overwinnen (68).

Zoo was de slagorde van de legeraanvoerders, die zich opstelden en zich tegenover elkaar stelden; onmiddellijk daarna trokken zij op. $\mathrm{Zij}$ maakten een geraas als wilde geduchte leeuwen, alsof de Doodsgod nederdaalde. Hunne haren waren rossig en gekruld en verward als de gloed van het vuur. Hunne oogen waren uitpuilend, rood en glinsterend als gloeiende kolen, die voortdurend flikkeren (69).

Hunne pupillen bewogen zich trillend als de bliksem, vreeselijk om te zien. $\mathrm{Zij}$ waren zoo zwart als wolken in den regentijd; hunne kinbaarden waren verward en ruig. Hun adem was als een storm, verschrikkelijk en als een onweersstorm, ruischend en suizend. $\mathrm{Zij}$ schreeuwden en joelden en hieven een leeuwengebrul aan en sisten; hun geluid was te vergelijken met den donder (70).

Nadat zij geschreeuwd hadden, gingen zij hoe langer hoe meer vooruit, dronken en snel en raakten allen handgemeen. $\mathrm{Zij}$ hieuwen met krtala's en staken met messen en werpspiesen en stieten en wierpen met werpschijven en staken met krissen. $\mathrm{Zij}$ sloegen met stokken en zij beukten met knotsen en strikten en stieten met ploegijzers. Snel staken zij met dolken en beukten met knotsen (71).

De voortreffelijkste wagenmenners, dapper en moedig, draaiden stokken in hunne linkerhand. Strikken waren in hunne rechterhand; snel zweepten zij de paarden. De paarden sprongen op, onmiddellijk, zonder verhindering keerden zij terug en vielen zij alle aan. En zij, die op den wagen stonden, schoten hunne speren af en troffen de zijden, die doorboord werden (72).

Alle helden, die te paard zaten, beijverden zich vooruit te trekken en hun opmarsch was niet te vergeefsch. $\mathrm{Zij}$ wisten allen, welke vijanden gedood waren en welke niet zouden sneuvelen; onophoudelijk trokken zij voorwaarts. De lieden, die keken naar hen, die kwamen, kwamen te laat; ziende, dat de apen gestooten werden, vervolgden zij hen, als roofvogels; snel als de bliksem strikten zij hen en trokken hen voort (73).

En gepantserde helden, geducht en woest van inborst, waren onbedwingbaar. Zij knarstandden van woede in hun hart en hunne lippen trilden (krulden zich om ${ }^{2}$ ), omdat zij beten. Zij allen sneden en

\footnotetext{
1) Prthruitala is tevens de naam van de versmaat.

2) De beteekenis „knarsen”, die het woordenboek aan kuměrĕkĕt geeft, past hier niet.
} 
drongen aan en streden woedend, opdringende; alle apen werden in beweging gebracht. Golvende naderden zij de rivier in het ravijn, velen raakten beklemd en werden afgesneden (74).

Het leger der apen was vertoornd, omdat hunne makkers in het nauw gebracht werden en zij namen snel weerwraak. Zij stompten en besprongen hen(? ${ }^{1}$ ) en sloegen en beten en zij zweepten met hun staart. Het middlel der vijanden sloegen zij met hunne beide handen, zij omklemden en drukten het. Snel werden zij teruggestooten en heen en weer geslagen; hunne armen werden verbrijzeld en verpletterd (75).

Andere apen staken met hunne scherpe nagels; het was verbazingwekkend, zooals zij staken. De zijden der rākșasa's werden doorboord van achteren, terwijl zij hun achterste grepen. Bij anderen werden de oogen doorboord, zoodat zij vielen, gestuit, achterover zijgende, overwonnen. Het bloed spoot uit hun mond; zij werden verbrijzeld en verpletterd en bezwijmden, overstelpt door steenen (76).

En krachtige apen wierpen de paarden om, die hen naderden. Zij grepen vlakke, harde en scherpe steenen, geweldig als donderbeitels. De wangen der paarden werden verpletterd en verbrijzeld; zij vlogen verschrikt weg en hunne oogen vlogen er uit, al spattende, en hun nek brak, hun hart viel eruit en het bloed dwarrelde gruwelijk in hun neus (77).

De ruwe apen draaiden hunne halzen om; overmoedig staken zij en vlogen achteruit. De dappere rākșasa's drongen vooruit, overweldigend; hun hosíd was verdwenen. De apen vlogen weg, spottende, brutaal, terwijl zij vervolgd werden door de kwaadaardige rompen. $\mathrm{Zij}$ gingen weg, overweldigd wordende, naar de rivier, overwonnen, niet wetende, dat zij in ravijnen vielen (78).

De verbazend dappere apen trokken aan hunne voeten; ten gevolge van hun kracht viel het hen niet moeielijk. Zij overstelpten het leger der rāksasa's met gespleten rotssteenen, waardoor hun borst gewond werd. De apen bewogen zich op de wijze van kinderen; zij klommen op hen en overstelpten hen. Zij stegen op de ruggen der reuzen. trachtende hen te overweldigen; verbaasd juichten zij luidkeels (79).

Andere apen vlogen en streken neder, terwijl zij de handen der vijanden grepen. $\mathrm{Zij}$ waren zeer ruw en kenden geen genade, op de

1) Hier schijnt māmrěkĕsět iets anders te beteekenen, dan „wringen”, zooals het woordenboek opgeeft. 
heup der rākşasa's zittende. Zij werden ellendig gekweld, gekwetst en gescheurd, zoodat het scheen, alsof hun lichaam geen lichaam was; wat de apen in het luchtruim betreft, die waren in grooten getale en beten allen vertoornd (80).

Als leeuwen waren de apenvorsten; zij stompten en sloegen met hunne handen. Het gestolde bloed kleefde aan hunne handpalmen, terwijl zij hen bij de haren grepen en hen in het gelaat sloegen. De reuzen vochten woedend en omvatten hen, afwisselend hen bijtende; wrevelig omdat zij geslagen werden, sloegen zij terug. Zij trachtten hen op den neus te slaan en klemden zich vast en wederom werden hunne tanden gebroken en afgeknot (81).

En de $r \bar{a} k s ̧ a s a$-helden streden in het woud, uitermate verschrikkelijk. Hunne bogen waren zoo groot als een wijnpalmboom, als een elleboog, hunne pijlen zoo dik als een vrucht, en de afmeting van hunne pijlen, hun punt was een vadem lang en het vooreinde was scherp en vlijmend( (?) $\left.{ }^{1}\right)$ Dat was hun schietwerktuig, als de slagtanden van Kāla om te zien (82).

De apen waren uitgeput, toen zij beschoten werden en hun hals viel gebroken en geknot op den grond. Anderen waren er, wier zijde getroffen werd en hen op hunne zijde dragende, vlogen zij weg. Vele apen werden ter zijde geraakt en hunne zijde scheurde, zoodat die bijna brak. Zij zuchtten en kermden voortdurend, vervoerd wordende, in ellendigen toestand, hevig gewond (83).

Andere rākșasa's schoten met scherpe sporen, wier punten alle troffen. En hunne $n \bar{a} r \bar{a} c a$-pijlen snorden in menigte en bleven steken in de apen, die getroffen werden. Scherpe pijlen staken in (?) $\left.{ }^{2}\right)$ hun heup, sterk en stevig, vreeselijk staken zij vast in hunne knieën. De ribben van hen, die getroffen werden, werden verbrijzeld en verpletterd; velen werden versplinterd en hunne $\ldots{ }^{3}$ ) werden gebroken, als zij getroffen werden (84).

Het apenleger werd hoe langer hoe zwakker, uitgeput en vernietigd; velen werden getroffen, mismoedig en bewegingloos; hunne aderen werden gewond door de houwers en hunne spieren werden doorgesneden. $\mathrm{Zij}$ vielen in zwijm en anderen vlogen weg en werden

\footnotetext{
1) De beteekenis ,ontbloot”, die de woordenboeken aan „měngĕs" geven, past hier niet.

2) Hitu ontbreekt in Van der Tuuk's K. B. Wdb. De vertaling ,staken in” is onzeker.

3) Welk lichaamsdeei met purĕn bedoeld wordt, is mij niet bekend. Het ontbreekt in de woordenboeken.
} 
weggeslingerd; omdat zij getroffen werden, vielen er velen. Zij bewogen zich onrustig, ontredderd; vervolgd wordende, vluchtten zij terug, door pijlen achtervolgd (85).

Toen de apen voortgeduwd werden en voortgedrongen en teruggedreven, werden zij verslagen en verdelgd. In beroering gebracht en getrapt wordende, kermden de kleine apen; anderen werden gestooten en omvergeworpen. De rākșasa's in het woud juichten, weerwraak nemende, tandenknarsende en fel aanvallende; als tijgers, die reebokken zien, vervolgden zij hen, dringende, om hunne hoofden te bemachtigen (86).

Toen Sugriwa zag, dat de apen in het nauw gebracht werden, sprak hij tot Nala: „Foei, Nala! Het goede (schoone) wordt slecht, als uwe makkers overwonnen worden; beveel hen, zich in te spannen! Laten Nìla en Anila's zoon zich niet stilhouden, maar laten zij alle apen aansporen, want het is niet de aard van spelende tijgers ${ }^{1}$ ), om te vluchten" (87).

Vervolgens nadat de voortreffelijke apenvorst gesproken had met Māruti, Nala en Nīla, traden de drie dappere helden vooruit, het apenleger tot dapperheid aansporende, om vooruit te trekken (88):

„Mannen, helden van het apenleger, gij die beroemd zijt als de dapperste in de wereld! Uw roem is uitermate rein. Het zou zeer te betreuren zijn, als die door u bezoedeld werd (89).

„Immers gij zijt vroeger onderricht in de wetenschappen, die voor $\mathrm{u}$ verhaald werden en die u uitgelegd werden. Wat is er toch voor reden om zeer bevreesd te zijn, naar uwe meening? Wat is het overwonnen worden van helden in den strijd? (90).

„Wat is toch de strijd, naar uwe meening? Immers de hemel wordt daardoor bereikt. De heldenmoed is de rechtvaardiging ervan. Roem en verlossing zijn de belooning ervan (91).

„Als men echter zeer bevreesd is, dan zal zeker de slechtheid hier toenemen. Het zweet vloeit en besproeit, de hel en de schande zijn de gevolgen, die ondervonden zullen worden (92).

„En dit behoort door u gedaan te worden. Het volgen van zijn aard veroorzaakt volmaaktheid. Wanneer gij maakt, dat uw aard onrein is, zult gij in de hel komen en te schande gemaakt worder. in de wereld (93).

„Wat is het nut ervan, dat gij vele dienaren hebt, wanneer de

1) Çārdülawikrị̂ita is tevens de naam van een bekende versmaat (Wṛttasañcaya, 88). 
bevelen van den vorst niet volbracht worden, want dit is passend, om door u gedaan te worden: het gehoorzamen van de bevelen van den vorst moet door $u$ verricht worden (94).

„Het sterven van $\mathrm{u}$ is niet doelloos, want daardoor zult gij $\mathrm{u}$ roem verwerven. Vroeger toen uwe vijanden overwonnen werden, werdt gij ongetwijfeld geprezen op aarde; roem, geluk en de wereld van Wiṣnu werden door $\mathrm{u}$ verkregen (95).

„Een Brahmaan is trouw aan de heilige geschriften, prevelt gebeden en verricht devotie ; een vorst (kșatriya) is een onvergelijkelijke held op aarde. Een Waiçya moet de sawah's bewerken en handeldrijven. Gij echter moet de bevelen van uwen vorst volbrengen (96). „Daarom moet uw geheele leger er naar streven, de overwinning uwer vijanden te weerstaan. Het is immers moeielijk voor hem, die streeft; alles wat hij beoogt zal zeker slagen (97).

.,De oceaan en het luchtruim zijn niet ruim; zelfs het ongebaande en verschrikkelijke woud is licht. De top van den Meru is zelfs laag, naar de meening van hem, die zich inspant en hooghartig is (98).

„Het binnendringen in de hellen pātāla en nitala zal slagen, alsmede in een hol, waar een tijger in huist. $\mathrm{Al}$ is het duister in de Raurawahel en in het hellevuur, dit alles vreest niet hij, die (naar iets) streeft (99).

„Doch het rākșasa-leger en de trekdieren, maakt die af, draait hen rond, vernietigt en overstelpt hen! De belooning van uw heldenmoed zal zeker gevolgen hebben; het sneuvelen bij de overwinning op het slagveld (brengt) verlossing" (100).

Zoo waren de woorden van Anila's zoon. Nala en Nīla vermaanden hen tegelijk. Het gevolg was, dat alle apen zich herstelden; de aard der helden werd door hen gevolgd ${ }^{1}$ ) (101).

Alle genietingen der troostende woorden werden door hen genoten(?); het was alsof hun hart met nectar besproeid werd. Hun heldenmoed nam hoe langer hoe meer toe, alsof hun vrees weggevaagd was (102).

$\mathrm{Zij}$ namen allen hunne wapens weder op; sommigen knotten in hunne driestheid bergen af. Hooge boomen werden door hen uitgetrokken; de bonte bloemen ${ }^{2}$ ) ritselden (103).

Nadat zij volledig toegerust waren, trad het apenleger zeer onstuimig naar voren. $\mathrm{Zij}$ rukten voorwaarts, stootende met boomen en

1) Het woord udah ontbreekt in de Oud- en Nieuwjavaansche woordenboeken.

2) Kusumawicitra is de naam van een bekende versmaat (Writtasañcaya, 59). D1. 86. 
lontar-, sommigen met arèn-palmen. Er waren er, die stieten met kokospalmen, terwijl anderen die als knots gebruikten. $\mathrm{Zij}$ wierpen en sloegen en beukten en anderen wierpen met bergen (104).

De reuzen waren uitgeput; zij schoten met pijlen, (doch) hunne pijlen werden getroffen en weggeworpen. Snel werden zij teruggedreven en rondgedraaid; hunne armen werden getroffen, geraakt en gestooten. Er waren er, die hun boog spanden en juist aanlegden, toen hun pijl gegrepen werd. $\mathrm{Zij}$ (hunne armen?) werden verpletterd, verbrijzeld en vermorzeld, doordat zij geslagen, gewelddadig behandeld en gebeukt werden (105).

$\mathrm{Zij}$ zegen achterover en anderen werden gestooten en op de knieën geworpen en op zijde geduwd; velen werden voortgeduwd, ineengezonken, onbewegelijk, in zwijm gevallen en verdelgd; hunne gewrichten werden gebroken. Er waren er, die kermden, omdat zij geslagen werden, terwijl twee van hen een weinig geraakt werden. Zij werden meegesleept door de apen en gesteenigd, (zoodat) hunne hersenen er uitspatten (106).

Er waren reuzen, die woedend streden als tijgers, alsof zij niet zouden sneuvelen, wanneer $\mathrm{zij}$ vooruittrokken. $\mathrm{Zij}$ waren zeer wrevelig in hun gemoed, omdat zij gegrepen werden en zij sloegen hunne armen om hen (de apen) en trachtten te bijten. De apenvorsten bewogen zich snel en sloegen met knotsen en omvatten hen (de reuzen) en drukten hun keel dicht. $\mathrm{Zij}$ (de apen) overstelpten de reuzen met steenen; hun hoofd werd fijngestampt en verbrijzeld (107).

Er waren er, die stootten met hunne bogen en anderen, die staken met vergiftigde pijlen. Zoo snel mogelijk sloegen zij met hunne bogen, zeer vertoornd. De apen waren zeer moedig en ontweldigden snel den rāksasa's hunne bogen. De reuzen vielen in zwijm en op hun beurt werden hunne bogen vernield (108).

Hoe langer hoe grooter werden hunne verliezen, omdat zij gegrepen en verdelgd werden; verscheidenen werden gewond, doch zij waren niet bevreesd en trachtten allen tegenstand te bieden en zij beraadslaagden, hoe zij den vijand zouden verslaan. Zij hielden op met hunne bogen te spannen, doch grepen hunne zwaarden en bijlen. Zij vatten lansen aan en messen en krtala's alsmede ploegijzers en strikken (109).

$\mathrm{Zij}$ traden vooruit, dringende, houwende, duwende, vervolgende en ronddraaiende, doch de apen waren niet bevreesd en duwden ook, terwijl zij krachtig ${ }^{1}$ ) geduwd werden. Op hun beurt sloegen zij (de

\footnotetext{
1) Sära kan lier opgevat worden als Skr. sāra (kern, merg., kracht) of als
} 
apen) geducht bijtende en stekende met hunne harde nagels. Zij werden met hamers geslagen en snel gestoken ${ }^{2}$ ) en gestrikt, zoodat zij uitgeput neervielen (110).

De $r \bar{a} k s ̧ a s a ' s$ traden naar voren en sloegen de apen met knotsen, terwijl zij door strikken getroffen werden. $\mathrm{Zij}$ werden tegemoet gegaan met werpspiesen en gestoken en wederom werd hunne zijde getroffen. Anderen werden weggeslingerd en gestooten en vielen, getroffen door lansen. De apen waren bedreven en kundig in het slaan en sloegen terug zonder dat zij teruggeslagen werden (111).

Hoe langer hoe woedender werd het $r \bar{a} k s ̧ a s a$-leger en het apenleger. $\mathrm{Zij}$ werden gedrongen en drongen en zij overwonnen; ook waren er, die verslagen werden, zoodat zij terugkeerden. De apen en de reuzen raakten handgemeen, vreeselijk, zoodat het was, alsof zij kwaadaardige leeuwen en tijgers waren. Hunne dapperheid was buitengewoon verwonderlijk, als de onwankelbaarheid van een berg ${ }^{3}$ ) (112).

Evenzoo werden de olifanten gepantserd; hunne slagtanden waren zeer scherp, vlijmend en puntig. Uitgelaten maakten zij hun geluid, dol en kwaadaardig, buitengewoon, evenals de vorst der zonenolifanten (113).

Zij nu trokken ten strijde in de moerassen, moedig standhoudend; als een veld was hun slagveld. Anderen trokken in ravijnen en wouden; de wouden waren propvol, velerlei, ontelbaar (114).

Al wat zij betraden werd verwoest, telkens zoo door hen behandeld ${ }^{4}$ ); nadat hun kracht goed gekeurd was, trokken zij alle vooruit. De apenvorsten gingen voorwaarts, in dichte drommen; zij beraadslaagden, allen wenschende, de olifanten te verslaan (115).

$\mathrm{Zij}$ grepen geweldige knotsen, een vadem dik; vernietigende sloegen zij daarmede allen tegelijk. Anderen wierpen met vlakke steenen; de apen slingerden al vliegende bergen tegen hen (116).

De zeer krachtige apen stegen en klommen, staandé op hunne ruggen; op de hielen volgende, zeer gewelddadig duwden zij tegen hunne ribben, hen isoleerende. Er waren er, die duwden tegen hunne hoofden en kelen (117).

Er waren er, die kwamen met palu-palu's (stokken of werktuigen

Middeljav. sara, dat "tevens, tegelijkertijd” schijnt te beteekenen, o.a. in den Malat.

2) Ginala beteekent waarschijnlijk: „met een lans gestoken”, van galah „lans”.

${ }^{3}$ ) Çikarini beteekent tevens ,met een krans getooid” en is de naam van een versmaat. Vg1. Writtasañcaya, 83.

4) De vertaling van lägi lěkasan is onzeker. 
om mede te slaan), die zij ronddraaiden; zij beukten op de snuiten der groote olifanten. Hunne slagtanden werden door hen omvat en alle afgebroken; zij staken hunne oogen uit, daarop mikkende, (zoodat zij) krachteloos werden (118).

De olifanten werden afgemat, van alle kanten aangevallen, woedend aangegrepen, overstelpt, geslagen en geduwd. Hunne pantsers werden gebroken, verpletterd en verbrijzeld; de kracht der apen was verbazend groot (119).

Evenzoo werden de ribben der olifanten geknakt; hunne ingewanden hingen er uit en hun bloed vloeide. Zij vielen, getroffen door těcbčng's ${ }^{1}$ ) en geslagen wordende; zij kermden en kreunden en verbijsterd stierven zij (120).

Anderen waren er, die zij (zich) lieten achterovervallen op hun rug; hunne kaken en hun hals werden doorstoken. Hun borst werd gestooten, geschopt en geduwd; hunne pooten werden omgedraaid, (zoodat) zij alle vier braken (121).

Ook waren er, wier aars gescheurd werd en opengereten; fluks werden zij aan het wankelen gebracht en vielen zij op hunne knieën. Hun hals werd omvat en hun lichaam boog voorover; hunne slagtanden, die wit waren, werden geknakt als Crinum asiaticum (122).

Iedere olifant, die vooruittrad, stierf en werd afgemaakt, doch zij verminderden niet; verscheidene lagen opgestapeld en opgehoopt. Ook waren er, die streden in een diepe rivier; de olifanten waren bedreven in het afdalen in het hoogstaande water ${ }^{2}$ ) (123).

Vervolgens, toen de legers tegelijk slaags raakten, hielden zij stand, doch er was niemand, die terugdeinsde. Onstuimig en onbevreesd was hun gemoed; zelfs als zij dachten te zullen sneuvelen, aarzelden zij niet. Allen werden zij vernietigd en verdelgd, woedend aangevallen en woedend aanvallende, overweldigend, terugslaande en teruggeslagen wordende; sommigen werden in eens afgemaakt, anderen waren half dood; doorstoken, kermden en zuchtten zij (124).

Hunne oogen gluurden, hun tong was uitgestoken, hunne ingewanden puilden uit en hun bloed vloeide. Het bloed bedekte hun gelaat, dat verpletterd en verbrijzeld was en hunne wangen werden met vuisten en hamers geslagen. Hun hals werd omgedraaid, hunne handen beefden en hunne voeten trilden en spartelden. Hun borst

\footnotetext{
1) Dit schijnt de naam van een wapen te zijn. Van der Tuuk (II, 814) heeft een stam tubabing.

2) Jaloddhatagati is tevens de naam van een versmaat. Vgl. Wṛttasañcaya, 60.
} 
werd gebroken, geslagen, gestoken en gescheurd, gespleten ${ }^{1}$ ) en opengereten (125).

Hunne vingers werden verscheurd en verwond, gebeten door de apen, die waren als manleeuwen. Hun borst werd verscheurd, opengereten en in honderd stukken gescheurd; hun fijne huid veranderde niet. De rug van hen, die bekropen werden, werd getrapt; hun middel werd geduwd, geknakt en gebogen. Hunne knieën scheurden uiteen, ontveld en verbrijzeld, gewond door hunne harde nagels (126).

Sommigen werden geslingerd, deerniswaardig, getrokken en geworpen vielen zij, door een halang (soort wapen) getroffen ; gepijnigd, vertrapt, teruggeslagen, vlogen zij onopgemerkt bevreesd weg. Anderen lieten de tanden zien, ijzende, ... ${ }^{2}$ ); men zou denken van hen, dat zij bevreesd waren, te zullen sterven. Pas stonden zij op en traden naar voren, om te vergelden, naar zij meenden, doch $\mathrm{zij}$ waren te laat en werden voorkomen, vernietigd en woedend aangevallen (127).

Er waren met bijlen gewapende, uitgelezen helden, goede wachters, voortreffelijke en sterke rākșasa's. Zeer krachtig en onstuimig vielen zij aan als de wind, ziende dat de apen vielen. Bij tien tegelijk werd in een oogenblik de hals afgesneden en de nek gebroken, (zoodat) zij omrolden. Zij beukten en troffen samen en botsten tegen elkaar, omdat zij voortdurend vielen en omvergesmeten werden (128).

Hoe langer hoe dichter opeengestapeld waren de lijken, naar het er uitzag; anderen waren bezeerd ${ }^{3}$ ), naar vermogen, honderden, tienduizenden, millioenen, honderd millioenen, prayuta ${ }^{4}$ ), honderdduizenden, tienduizenden. Het samenstroomen van het bloed der lijken was zoo verbazend, dat de diepte ervan tot de borst reikte. Olifanten, wagens en voetgangers verspreidden zich, uitgeput; de zich verlustigende paarden (açwalalita) ${ }^{5}$ ) werden gedrukt (129).

Buitengewoon verschrikkelijk was het slagveld; alles was rood.

1) Voor tumihuk in den tekst leze men: tinuhuk.

2) Uläsa cntbreekt in de O. Jav. woordenboekcn. Misschien is de woordscheiding verkeerd en moet men lezen: ulā salinga. Dan is de vertaling: als slangen, „men zou meenen”, enz.

3) Tajar is volgens V. d. Tuuk (K. Bal. Wdb. II, 735) = papacĕk, bezeerd.

4) Prayuta beteekent in het Sanskṛt ,millioen”, doch deze beteekenis wordt in het O. Jav. aan koṭi gegeven, dat in het Sanskṛt ,tien millioen beteekent. Hier schijnt prayuta in de beteekenis van ,duizend millioen” gebruikt te zijn. Lakşa, dat in het Sanskṛt ,honderdduizend" beteekent, heeft zooals men weet, in O. en N. Javaansch de beteekenis ,tienduizend".

5) Açr'alalita is de naam van een bekende versmaat (Wṛttasañcaya, 94), 
Het meer van Yama zou zoo schoon zijn, als het afdaalde. Het bloed was te beschouwen als het water ervan, troebel, stinkend en vunzig. De vaandels, zwart, rood en sommigen wit, zou men kunnen vergelijken met het schuim (130).

De halzen der helden, die afgesneden waren, keken uitpuilend. $\mathrm{Zij}$ dreven in menigte in het midden als ontloken lotussen. Hunne ingewanden, die er uitstroomden en zich kronkelden, die waren als ranken. Uiterst rein was het slagveld, als het vergeleken werd met een meer (131). 